\title{
Fallen and Cross-Border Literary Commemoration, 1916
}

\section{Katherine Side and DeNel Rehberg Sedo}

\section{(2) OpenEdition \\ 1 Journals}

\section{Electronic version}

URL: https://journals.openedition.org/etudesirlandaises/8127

DOI: 10.4000/etudesirlandaises.8127

ISSN: 2259-8863

\section{Publisher}

Presses universitaires de Caen

\section{Printed version}

Date of publication: 31 December 2019

Number of pages: $27-41$

ISBN: 978-2-84133-964-8

ISSN: 0183-973X

\section{Electronic reference}

Katherine Side and DeNel Rehberg Sedo, "Fallen and Cross-Border Literary Commemoration, 1916", Études irlandaises [Online], 44-2 | 2019, Online since 06 May 2020, connection on 18 November 2022. URL: http://journals.openedition.org/etudesirlandaises/8127 ; DOI: https://doi.org/10.4000/ etudesirlandaises.8127

\section{(c) (i) (2) (2)}

Creative Commons - Attribution-NonCommercial-ShareAlike 4.0 International - CC BY-NC-SA 4.0

https://creativecommons.org/licenses/by-nc-sa/4.0/ 


\title{
Fallen \\ and Cross-Border \\ Literary Commemoration, $1916^{*}$
}

\begin{abstract}
We analyse the centenary-focused, jointly programmed, "One Book Two Cities" mass reading event organised around Lia Mills' title, Fallen, in Dublin and Belfast in 2016. Drawing on Sarah Pink's theory of the place-event, we analyse this mass reading event through event programmes, press releases, newspaper articles, and social media platforms. This mass reading event challenged readers to consider how books were changed by place, and challenged organisers to consider how places were transformed by readers and books. Based on analyses of programmatic activities, we argue that this cross-border activity allowed organisers to engage with the 1916 commemorative programme and participate in the aspirational goals of literary reconciliation, but it permitted them to do so in ways that avoided contested narratives about history, nation, and gender. Historical commemoration in "One Book Two Cities" demonstrates how contemporary politics of commemoration in the Republic of Ireland and Northern Ireland continue to be inflected with their historical entanglements.
\end{abstract}

Keywords: Dublin, Belfast, commemoration, mass reading events, gender.

Résumé: Cet article s'intéresse au projet “One Book Two Cities", coproduit par les bibliothèques publiques de Belfast et Dublin, à l'occasion du centenaire du soulèvement de 1916, et à la lecture publique du roman de Lia Mills, Fallen, qui fut organisée à cette occasion. Il utilise le concept de l'«événement-lieu» tel que l'a théorisé Sarah Pink, et s'appuie sur des sources secondaires variées: programmes, coupures de presse, articles de journaux et plateformes multimédia. La lecture publique de grande ampleur de Fallen a encouragé les lectrices et lecteurs à s'interroger sur la façon dont un lieu peut changer la réception d'un livre et a, inversement, invité les organisateurs de l'événement à réfléchir à la manière dont un lieu peut être transformé par un livre ou la présence de lectrices et lecteurs. Cette lecture transfrontalière a permis aux organisatrices et organisateurs de participer aux commémorations de 1916 et les a amenés à s'interroger sur le rôle de la littérature dans le processus de réconciliation, tout en évitant les polémiques que des récits historiques, ou des concepts tels la nation ou le genre peuvent susciter. Le projet "One Book Two Cities" montre que les politiques commémoratives de la République d'Irlande et de l'Irlande du Nord continuent d'être infléchies par la nature et la représentation des conflits passés.

Mots clés: Dublin, Belfast, commémoration, lectures publiques, genre.

* The authors thank all those who shared their knowledge, resources, and ideas that differed from their own. Thanks to Danielle Fuller for her helpful insights on an earlier draft and to anonymous reviewers. 
A century after the Easter 1916 Rising, Lia Mills' novel, Fallen, was selected as the inaugural Dublin-Belfast, "One Book Two Cities" title. Fallen was re-issued with a cover imprint of a figurative bridge hovering over an open book. In this article, we identify the "One Book Two Cities" mass reading initiative as a form of literary commemoration and assess its ability to address literary reconciliation through joint commemoration between the Republic of Ireland and Northern Ireland ${ }^{1}$. We argue that the potential for what Robert Clarke and Marguerite Nolan refer to as "fictions of reconciliation" in post-colonial contexts is largely unrealised ${ }^{2}$. Our analysis brings together literary criticism, literary sociology, theory of place-events, commemoration studies, and gender studies to expose the tensions in this single literary event. We identify some of the logistical and political challenges of extending the one-book-one-place model across dual locations and across (still contested) borders. Our study was carried out in 2017-2018, two years after "One Book Two Cities" events took place. Because we were unable to conduct participant observation or talk with readers, we analyse "One Book Two Cities" programmes, press releases, newspaper articles, social media platforms, select participant evaluations, and our conversations with event organizers, an event presenter, and a member of Dublin's UNESCO City of Literature Committee ${ }^{3}$. "One Book Two Cities" was a bold initiative that confronted the long contested topic of commemoration and expanded textual and geographic engagement through the place-event. However, this initiative was limited by its inability to engage the two cities directly and by its problematic gendered politics of commemoration ${ }^{4}$.

We employ anthropologist Sarah Pink's concept of the place-event to frame and examine reader engagements in the mass reading event ${ }^{5}$. Mass reading events encourage large numbers of people to read the same book: "[...] organizers frequently select books because they articulate themes, issues, and ideas that are pertinent to the inhabitants of a locale" ${ }^{1}$. Book titles are selected for their geographical

1. For the one-book-one-place model, see Beth Dempsey, "One Book, One Community: One Great Idea”, Library Journal, vol. 134, no. 14, 2009, p. 19-22. This was not Ireland's first cross-border literary project; "Dialogues through Literature", 2013-2014, funded by the International Fund for Ireland, encompassed four border counties: Cavan and Leitrim (Republic of Ireland), and Fermanagh and Tyrone (Northern Ireland). This eighteen-month project involved book clubs in cross-border meetings, discussions, and excursions in English and Irish. Its aim was to challenge stereotypes, develop greater mutual understanding, and build cross-community relations (Fermanagh Herald, 15 July 2013).

2. Robert Clarke, Marguerite Nolan, "Book Clubs and Reconciliation: A Pilot Study on Book Clubs Reading the 'Fiction of Reconciliation'”, Australian Humanities Review, vol. 56, 2014, p. 121.

3. See Anouk Lang, "Enthralling but at the Same Time Disturbing: Challenging the Readers of Small Island”, The Journal of Commonwealth Literature, vol. 44, no. 2, 2009, p. 123-140.

4. The year-long 1916 commemorative programme included over 4,500 events, enabled by a $€ 49$ million budget (Christopher Cusack, Marguérite Corporaal, Ruud van den Beuken, "Never Forget? Memory's Role in Irish Culture", The Irish Times, 10 February 2017).

5. Sarah Pink, "From Embodiment to Emplacement: Re-Thinking Competing Bodies, Senses and Spatialities", Sport, Education and Society, vol. 16, no. 3, 2011, p. 345.

6. Danielle Fuller, James Procter, "Reading as 'Social Glue'? Book Groups, Multiculture, and the Small Island Read 2007”, Moving Worlds: A Journal of Transcultural Writings, vol. 9, no. 2, 2009, 
boundedness; yet, they are expected to do the contradictory work of appealing to a diverse group of readers ${ }^{7}$. Reader perspectives are often brought together in library-based book clubs, in face-to-face and virtual conversations, and through book-related excursions to places, or place-events ${ }^{8}$. Organisers of place-events move readers through places associated with the text and reach beyond the pages to encompass natural and built environments ${ }^{9}$. Pink argues that places and their meanings become events through participants' movement and mobility and through interpersonal contacts and sensory experiences ${ }^{10}$. The place-event shifts the personal experience of embodiment towards a sense of emplacement and builds emotional, physical, and/or sensory attachments to books, their stories, and to places that make them meaningful ${ }^{11}$. The book-related place-event becomes a literary performance through which readers can better understand stories, including those told about and by others ${ }^{12}$. Place-events are enacted, intentionally, to make reading memorable ${ }^{13}$. The "One Book Two Cities" initiative, funded by Dublin City Council, the Department of Foreign Affairs' Peace and Reconciliation Fund and UNESCO, used the occasion of the 1916 centenary to invite participants on both sides of the Irish border to participate in reshaping the history and legacy of North-South relationships ${ }^{14}$.

Against the complex history of partition of the island of Ireland, we briefly outline Fallen's plot and its commemorative significance. We examine and spatially map out urban place-events and assess uses of the place-event in the creation of literary cityscapes in Dublin and Belfast. We consider the ways that histories and people were mobilised and immobilised in "One Book Two Cities". We demonstrate how some place-events were intentionally transformed into programmed cityscapes that highlighted North-South distinctions and replicated the gendered politics of commemoration and women's exclusion as experts. These challenges, we suggest, are not a shortcoming of Fallen or the event organisers; they represent the challenges of expecting that a single literary text can link cross-border commemorative histories, events, and practices.

p. 28. See the American Library Association 2003 guidelines for "One Book One Community" programmes, on line: http://www.ala.org/tools/sites/ala.org.tools/files/content/onebook/files/ onebookguide.pdf.

7. Beth Dempsey, “One Book, One Community...”, p. 19.

8. For Dublin book clubs, see Dublin City Council website, 2016, http://www.dublincity.ie/main-menuservices-recreation-culture-dublin-city-public-libraries-and-archive-events/book-clubs.

9. Dublin sponsors of “One Book Two Cities" included Dublin City Public Libraries, Department of the Arts, Heritage and the Gaeltacht, and RTÉ Supporting the Arts.

10. Sarah Pink, "From Embodiment to Emplacement...".

11. Ibid.

12. Sarah Pink, "The Future of Sensory Anthropology", Social Anthropology, vol. 18, no. 3, 2010, p. 333.

13. Danielle Fuller, James Procter, "Reading as ‘Social Glue'?...”, p. 38; Sarah Pink, "From Embodiment to Emplacement...", p. 343.

14. "Dublin and Belfast have fallen for One Book Two Cities", "Dublin: One City, One Book" website: http://www.dublinonecityonebook.ie/news/dublin-and-belfast-have-fallen-for-two-cities-onebook-festival. 


\section{Fallen}

Mills' third novel, Fallen is a fictional account of events surrounding the 1916 Easter Rising. The novel's protagonist, Katie Crilly, is a bright, ambitious twenty-two-yearold university graduate whose twin brother, Lieutenant Liam Crilly has been killed in battle while serving in World War I with the Royal Dublin Fusiliers. The novel, set across central Dublin, unfolds against the disarray of the 1916 Rising, a rebellion against British rule in Ireland ${ }^{15}$. The struggle for an independent Ireland divides those fighting for Great Britain in the Great War, from those fighting for Ireland in its Easter Week rebellion. Katie Crilly struggles with her bereavement, along with the difficulty of finding a place in a society that offers women few opportunities. She struggles with her feelings for two men whose militarism and heroism are celebrated and condemned: her twin brother, Liam and his fellow soldier, Captain Hubie Wilson. The book's title, Fallen, hints at the different meanings of the word for men fallen in battle and for women fallen in immorality and despair.

\section{Literary cityscapes}

"One Book Two Cities" builds on previous mass reading traditions established in Dublin since 2006, and in Belfast since 2011. Dublin's UNESCO City of Literature designation lends further credibility to the event goals: "(1) mark the $100^{\text {th }}$ anniversary of the 1916 Rising in a positive, appropriate way; (2) link cross-border communities through common experiences; (3) foster cross-border understandings; and (4) provide an opportunity to create a legacy through the practice of book-club twinning" ${ }^{16}$. Event publicity encouraged people from Dublin and Belfast "to read, talk about and openly debate the [...] novel, whether in libraries, online, on trains, in coffee shops or anywhere that people feel comfortable to read and discuss" ${ }^{17}$. By inviting readers to participate in their own North-South dialogue and in existing commemorative practices, this initiative shifted attention away from other, fractured politics of commemorations, such as the $50^{\text {th }}$ anniversary of the outbreak of Northern Ireland's violent civil conflict ${ }^{18}$.

15. These were complicated alliances; some Irish soldiers who fought for Great Britain in World War I believed their efforts would be rewarded with an independent Ireland. See Fearghal McGarry, The Rising. Ireland: Easter 1916, Oxford, Oxford University Press, 2011.

16. Jackie Lyman (member, Dublin UNESCO City of Literature Committee), 2017, personal communication.

17. "One Book One City", programme, 2016.

18. On reading and citizenry, see Danielle Fuller, Citizen Reader: Canadian Literature, Mass Reading Events and the Promise of Belonging, London, The Fifth Eccles Centre for American Studies Plenary, 2011, on line: http://vll-minos.bl.uk/eccles/pdf/bacs2010.pdf. On commemoration, see Roisín Higgins, "Women and the Decade of Commemorations: An All-Island Perspective of 2016", 2 February 2017, on line: https://mucommemorations.wordpress.com/2017/02/02/women-andthe-decade-of-commemorations. Also see, Jim Collins, Bring on the Books for Everybody: How Literary Culture Became Popular Culture, Durham, Duke University Press, 2010. 
Book-related events were mapped onto their respective cityscapes in Dublin and Belfast. However, they reflected the difficulties of two separate jurisdictions, each with their own distinctive history and commemorative practices ${ }^{19}$. "One Book Two Cities" organisers chose to emphasise commemoration of the Rising in Dublin, and commemoration of World War I in Belfast, with a less prominent programmatic focus on women's emancipation and education in both cities ${ }^{20}$. This division may have minimised the possibility of political tensions. However, it also divided, rather than bridged, the places, cities, place-events and their commemorative practices. It simplified the historical significance of these events by dissipating the effects of World War I in Dublin and connections to the Rising in Belfast. As the Rising unfolded on the pages of Mill's novel and on Dublin's streets, Belfast receded into the background. The place-event became associated with Dublin as the location of the Rising, and Belfast's role in the jointly programmed event, as well as in shaping its legacy, became tangential.

Dublin's centrality is evident in the book dedication, "For the city", and in the story's location on the Dublin streets where Mills' parents lived, her mother above a shop on Parnell Street, and her father on nearby Merrion Row. Her characters display an urban mobility, "as an embodied practice for knowing" the city ${ }^{21}$. The main character and narrator, Katie Crilly guides readers along on her "usual route" down Sackville Street, turning "east along Great Denmark Street”, and later down "North Great Georges Street to escape the sun", as she winds her way to her sister's home "at the blind end of Ely Street" 22 . When the Rising occurs, her mobility ends abruptly. Instantly, city streets are transformed into unpredictable places with smashed furniture, broken windows, and soldiers preparing for rebellion. Fleeting speculation about the presence of Germans in the city ties the Rebellion loosely to World War I ${ }^{23}$. When Katie Crilly is ensconced in a safe house on Percy Place, her brother's injured comrade, Hubie Wilson lays out the dinnerware, a teapot, milk pot, sugar bowl, and a knife, to map the city landmarks and rebel positions. These familiar domestic items present the city as menacing ${ }^{24}$. The safe house on Percy Street becomes a place of refuge, and also the place where Katie Crilly is "fallen" by having an affair with Wilson, giving rise to her uncertain future.

19. The Decade of Centenaries (1912-1922) includes the Ulster Convenant (1912); the rise of the labour movement (1913); World War I (1916-1918); Easter Week and its Rising (1916); the Battle of the Somme (1916); Lloyd George's Irish Convention (1917-1918); women's suffrage and Ireland's general election (1918); the War of Independence (1919-1921); the Government of Ireland Act (1920); and, the Civil War (1922). They are common to both jurisdictions, but even within a jurisdiction, they are not weighted and acknowledged in similar ways.

20. Jackie Lyman, 2017, personal communication.

21. Lia Mills, "Podcast of Lia Mills UCD Writer-in-Residence Event", 10 May 2016, on line: http:// www.artscouncil.ie/News/Literature/Podcast-of-Lia-Mills-UCD-Writer-in-Residence-event. See Sarah Pink, "The Future of Sensory Anthropology".

22. Lia Mills, Fallen, London, Penguin, 2014, p. 12.

23. Ibid., p. 140.

24. Ibid., p. 190. 
I am the one who has fallen, now. How could one word mean such different things?

Those men in the afternoon, bleeding on the road. And me, warm in tangled sheets beside

- who was this man? Who was I, come to that, and what would the morning bring ${ }^{25}$ ?

Uncertainty is recreated in Dublin-based place-events. As readers walk through the city's familiar streets, they are urged to see and experience them in unfamiliar ways, including noting their historical significance.

Belfast's place in the novel is peripheral. Its only connections to the Rising are through comings and goings that are fleeting in duration and significance. Belfast appears in the form of the De Dion-Bouton car, manufactured by the Belfast-based Chambers Company ${ }^{26}$. Later, this same model car is sent to transport Liam's former fiancée to safety ${ }^{27}$. This car is no mere coincidence; it plays a key role in the Rising's mythology. Reportedly driven by Michael Joseph, “The O’Rahilly”, it was used to form part of a barricade on Dublin's Prince Street and is immortalised in a famous photograph of its burnt-out skeleton ${ }^{28}$. Belfast reappears when Kate Crilly learns the whereabouts of her missing younger brother, Matt who has travelled to Belfast with his theatre company, having sold his father's guns to finance the adventure. Belfast leaves no indelible mark on the novel's rebellion.

\section{Programmed cityscapes}

This imbalance in literary significance was mirrored in weakly connected, programmed cityspaces. Programmed events in Dublin were spread across the city and its suburbs. They engaged readers' mobility and senses across a wide programme that included theatre performances and dramatic re-enactments, lectures and readings, films, exhibitions and gallery tours, musical performances, and walking tours intended to "entangle" the book's plot and locations in complex social, spatial, and sensory relationships ${ }^{29}$. But, Belfast's status as a relative newcomer in promoting literary landscapes, its physical and literary distance from the Rising, and its demographic differences, including long-standing patterns of residential segregation and sectarianism, made the place-event a much trickier proposition ${ }^{30}$.

Places across Dublin were transformed into literary and commemorative destinations. Expansion of the novel's themes included considerations of wartime bereavement, the role of the Dublin Fire Brigade, and songs of $1916^{31}$. Fallen's

25. Lia Mills, Fallen, p. 231.

26. Ibid., p. 101.

27. Ibid., p. 170.

28. “The O'Rahilly - Cars: Cars belonging to the O'Rahilly”, on line: http://humphrysfamilytree.com/ ORahilly/the.orahilly.cars.html.

29. Sarah Pink, "From Embodiment to Emplacement...", p. 349.

30. Katherine Side, "Visual and Textual Narratives of Conflict-Related Displacement in Northern Ireland", Identities: Global Studies in Culture and Power, vol. 22, no. 4, 2015, p. 486.

31. See Libraries as Agencies of Culture, Thomas Augst, Wayne Wiegand (eds.), Madison, The University of Wisconsin Press, 2003. 
cover image appeared on Dublin City Council's website, on banners in public libraries, and in prominent public places, including the central transportation hub of Dublin's Connolly Station. The book's visual presence reinforced its commemorative significance ${ }^{32}$. Over fifty scheduled place-events were held across forty-one consecutive days in Dublin ${ }^{33}$. Acknowledging this to be a punishing schedule, Lia Mills suggested, to an audience at University College Dublin, that the city's residents were likely experiencing "1916 fatigue" and along with it, "Fallen fatigue" $(2016)^{34}$. Dublin venues were selected on the basis of their historical and / or cultural significance. They combined place and mobility into what Lawrence Grossberg calls "territorializing events", for their ability to produce and map "space and places" 35 . Readers could discuss Fallen in the Royal College of Surgeons, the building that had once been occupied by the Irish Citizen's Army and whose members built barricades from its library books ${ }^{36}$. They could listen to RTÉ broadcaster Joe Duffy discuss the children of the Rising's leaders in the National Library as the site where character Katie Crilly took typing lessons. Beyond Dublin, residents of Paris also participated in a book-related event at Centre culturel irlandais, where Mills wrote Fallen during a 2009 residency ${ }^{37}$ (fig. 1, p. 34).

Dublin's cityscapes were territorialised through historical accounts of the Rising, their re-enactment and commemoration, and through the mobility and sensory experiences of participants' "experiencing bodies" in places selected for their historical significance ${ }^{38}$. Organisers also established a digital presence. Anne Goarzin argues the screen provides an additional interface for "reworking national memories and their re-tellings", and creates "new forms of subjectivities", and Dublin organisers maintained a programmatic presence on Facebook, Instagram, and Twitter ${ }^{39}$.

32. Visibility did not assure sales. Children of the Rising, by RTÉ broadcaster, Joe Duffy (Dublin, Hachette Books Ireland, 2015), was the 1916 best seller. It topped the charts in the week ending 30 April 2016, with Fallen at number thirteen. See Aoife Kelly, "Joe Duffy's Children of the Rising tops book chart for Second Week in a Row”, Irish Independent, 28 October 2015.

33. Dublin's programme extended from 21 March 2016 until 29 April 2016. The busiest single day of programing was Tuesday, 19 April 2016, with seven events, and there were only two days during this period with no scheduled events.

34. Lia Mills, 2016.

35. Lawrence Grossberg, "Affect's Future: Rediscovering the Virtual in the Actual”, in The Affect Theory Reader, Melissa Gregg, Gregory Seigworth (eds.), Durham, Duke University Press, 2010, p. 313.

36. Nicholas Allen, "Rebellion, Objects, Empire and 1916", in Atlas of the Irish Revolution, John Crowley, Donal Ó Drisceoil, Michael Murphy, John Borgonovo (eds.), Cork, University of Cork Press, 2017, p. 236.

37. The Paris event also included Belfast-based visual artist, Gail Ritchie.

38. Sarah Pink, "From Embodiment to Emplacement...", p. 345.

39. Anne Goarzin, “The Rising Goes Digital: Century Ireland.ie”, Études irlandaises, no. 42-2, 2017, p. 75. Goarzin examines Century Ireland, an on line digitised newspaper project that commemorates events and daily lives in 1916 Ireland. Dublin City Libraries maintained the Twitter hashtag \#2cities1book. The Twitter account @KatieC1916 (no longer active) was scripted by Mills to encourage readers to follow the novel's central character. 


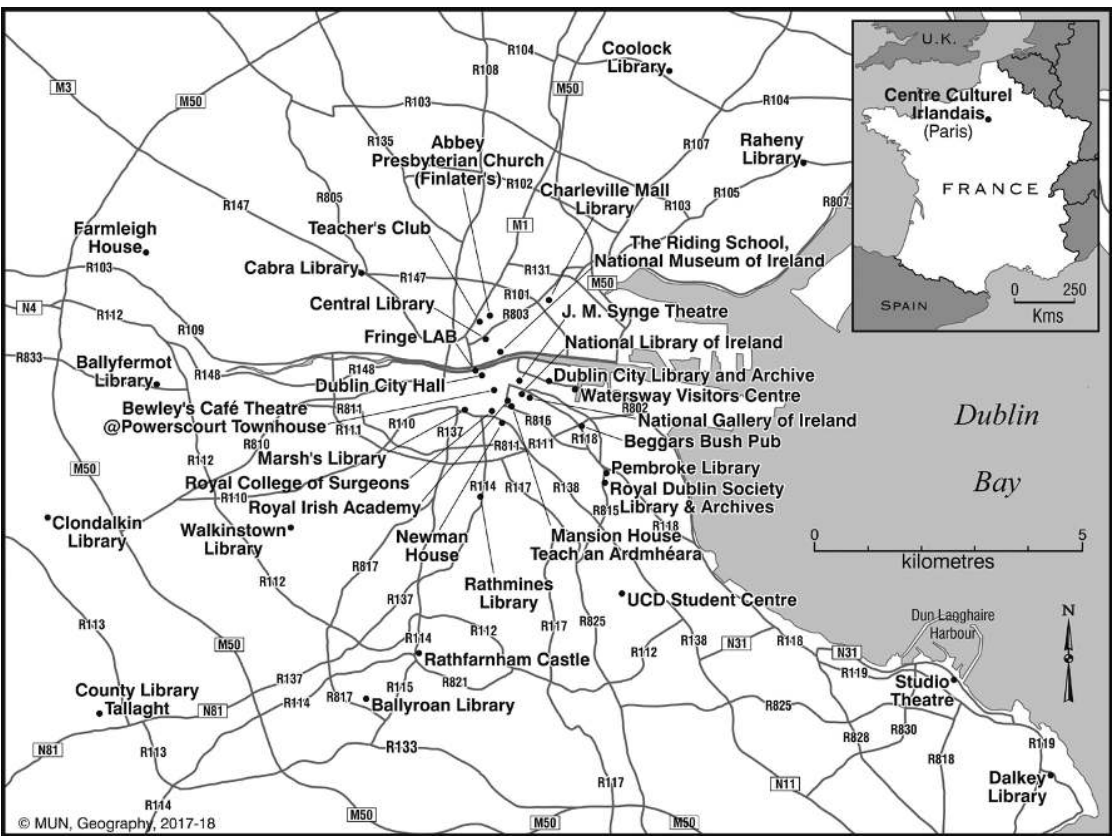

Fig. 1 - “One Book Two Cities”, 2016, events by locations, Dublin and France.

Charles Conway, Department of Geography, Memorial University.

Belfast's cityscapes were distant, physically and in a literary sense, from the Rising. Its long contested political terrain made the place-event challenging ${ }^{40}$. Northern Ireland's unionists, who prefer a political union with Great Britain, might have favoured a mass reading event focused on World War I, whereas nationalists, who favour a politically united island, might have favoured events connected with the Rising. Some Belfast residents, who were weary of the conflict and its legacy, could have been less welcoming of literary programming associated with the city's persistent divisions.

Eighteen Fallen-related events were held across Belfast during the first twentynine days in April 2016 (fig. 2).

In Belfast, the potential for political antagonism was managed by controlling event participants, places, and formats. Organisers sought to achieve perceptions of programmatic balance among communities, although as Neil Jarman argues, "an entwined tradition of commemorative ritual serves to emphasise two opposing senses of communal or ethnic identity and destiny", rather than to join them ${ }^{41}$. Participants in Belfast were limited to library-based book club membership, and "One Book Two Cities" programmes were held, almost exclusively, in public

40. Katherine Side, "Visual and Textual Narratives...".

41. Neil Jarman, "Pride and Possession, Display, and Destruction", in Flag, Nation, and Symbolism in Europe and America, Thomas Hylland Eriksen, Richard Jenkins (eds.), London, Routledge, 2007, p. 153. 


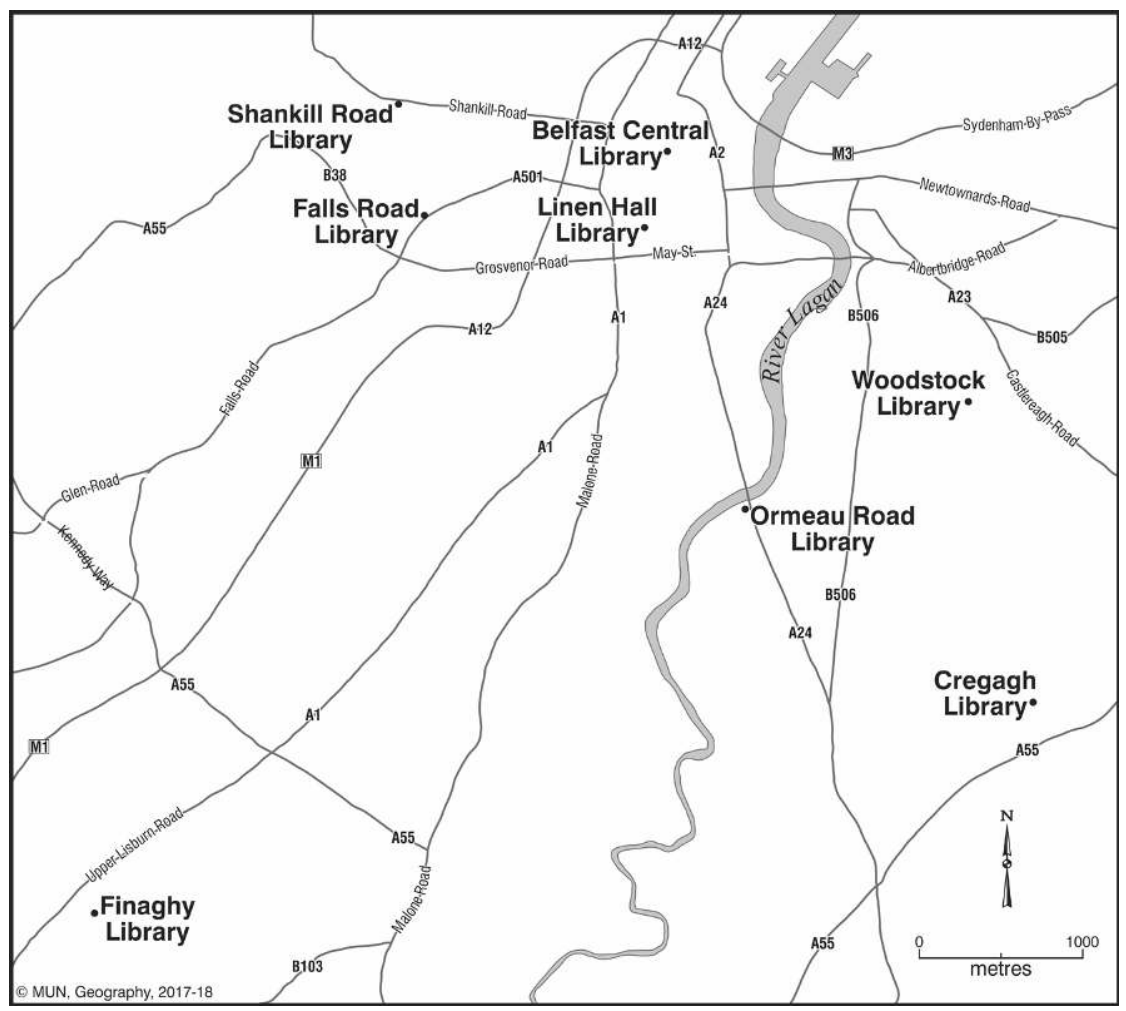

Fig. 2 - “One Book Two Cities”, 2016, events by location, Belfast.

Charles Conway, Department of Geography, Memorial University.

libraries. The city's libraries are regarded as neutral locations that must adhere to section 75 of the Northern Ireland Act 1998, Equality Act, legislation prohibiting discrimination ${ }^{42}$. In practice however, all except two libraries, both of them located in commercially-dominated South Belfast, were located in residentially segregated neighbourhoods ${ }^{43}$. Belfast's programming favoured digital places, including World War I related workshops. There were no place-events and organisers avoided moving participants through unfamiliar places. This sense of geographical and embodied

42. Northern Ireland Library Authority, Equalities Screen Summary, 2013, document accessed on line, no longer available (last accessed 23 April 2018).

43. Belfast's Central Library was a Fallen-related location and the former workplace of Elizabeth Corr, a library typist and Cumann na mBan (Women's League) member present in Dublin during the Rising. Cumann na mBan was founded in 1914. According to Margaret Ward, "Elizabeth Corr, and her sister Nell Corr, were amongst the first to see the Proclamation, memorising it in order to be able to tell people in the North about the Rising" (Margaret Ward, "Revolutionary Women of 1916", conference paper to the CAIS/ACEI (Canadian Association for Irish Studies / Association canadienne d'études irlandaises) Conference, "1916: The Easter Rising and Its Aftermath", Ottawa, 22 October 2016). 
confinement limited participants' opportunities for experiential and sensory learning and provided a sanitised re-imagining of place that related only distantly to the city's conflictual past. Social media engagement by Libraries Northern Ireland (Libraries NI) was limited to event announcements. These pragmatic differences ensured that "One Book Two Cities" remained embedded in a contentious commemorative politics, including its gendered politics.

\section{Gendered commemorative politics}

State-led 1916 commemorations have been plagued by assertions about women's exclusion ${ }^{44}$. A myopic view of authorship pre-dated the selection of Fallen, which was the first selection authored by a woman included in Dublin's decade-long mass reading events. In Belfast, a single selection by a woman was included previously ${ }^{45}$. The selection of Fallen did double duty, in the short term, by addressing women's exclusion as authors in mass reading events and their exclusion as experts in commemoration ${ }^{46}$. At the same time, the selection of a novel focused on two military conflicts might have attempted to rectify men's underrepresentation as book clubs members ${ }^{47}$. Event organisers speculated, without providing statistical support, that men's participation in 2016 was increased over previous mass reading events ${ }^{48}$. It was unclear if men participated as readers, participated in commemorative placeevents, or both. Women reader's participation may have been a reflection of what Beth Driscoll identifies as the association of the event's book club format with "a particular package of literary values - female, commercial, and middlebrow" 49 .

The imbalance in inclusion and expertise was evident across both cities. In Dublin, the Abbey Theatre's centenary programme, "Waking the Nation", instigated women's ire for their exclusion. In response, the \#WakingTheFeminists campaign led to the development and adoption of a gender equality policy for theatres ${ }^{50}$. In

44. See Ciara Murphy, "Reflecting Irishness, Mirroring Histories: Performing Commemoration in Irish Theatre in 2015", New Hibernia Review, vol. 20, no. 3, 2016, p. 112-124; Oona Frawley, "Women and the Decade of Commemorations: An All-Island Perspective", 2 February 2017, on line: https:// mucommemorations.wordpress.com/2017/02/02/women-and-the-decade-of-commemorations.

45. “One Book One City” Belfast chose Lucy Caldwell's, All the Beggars Riding (London, Faber and Faber, 2013), in 2013. In 2018, “One Book One City” Dublin selected Sinéad Gleeson's The Long Gaze Back: An Anthology of Irish Women Writers (Stillorgan, New Island, 2015).

46. Roisín Higgins, Transforming 1916: Meaning, Memory and the Fiftieth Anniversary of the Easter Rising, Cork, Cork University Press, 2012.

47. DeNel Rehberg Sedo, "Readers in Reading Groups: An Online Survey of Face-to-Face and Virtual Book Clubs”, Convergence: The International Journal of Research into New Media Technologies, vol. 9, no. 1, 2003, p. 67.

48. Jackie Lyman, 2017, personal communication.

49. Beth Driscoll, “How Oprah's Book Club Reinvented the Woman Reader”, Popular Narrative Media, vol. 1, no. 2, 2008, p. 139.

50. The Abbey's centenary programme include ten plays, including one playwright and three directors who were women, see Maureen Murphy, “Abbey Activists”, Irish Literary Supplement, vol. 36, no. 2, 2017, p. 20. The gender equality policy, supported by Department of Arts, Heritage and the Gaeltacht, 
Belfast, a display at Belfast's Central Library excluded the wartime contributions of one of its staff members, librarian Elizabeth Corr $^{51}$. Women were also underrepresented as experts on the cross-border Decade of Centenaries Expert Panel and were excluded from its leadership ${ }^{52}$.

In "One Book Two Cities" events, women outnumbered men as presenters. In Dublin, women presenters, forty in total, outnumbered men, thirty in total. In Belfast, sixteen women presenters edged past thirteen male presenters. However, women and men occupied different roles that upheld patterns of commemorative marginalisation ${ }^{53}$. At events, women presenters were less likely to be sole speakers, and were more likely to share the stage with other women. In Dublin's programme, women were three times more likely than men to share the stage ${ }^{54}$. In one instance, an all-women panel was chaired by a man, whose position permitted him to mediate a discussion about women's suffrage ${ }^{55}$. In the Belfast programme, half the women who spoke about the novel shared a platform with other women; a single man shared a platform.

Men's expertise was highlighted in both programmes, whereas women's was not. A Belfast-based event provided an extensive biography and listed the published books by a male historian; the biography of a similarly well-published female historian listed none of her published books. Superlatives, such as author of an "original ground-breaking anthology" described men ${ }^{56}$. Men tended to present on topics related to battles, court martial proceedings, and military experiences; women tended to present on topics related to civilian experiences, including bereavement, children, and fashion. Women's expertise was downplayed by relational descriptions that positioned them as "pondering", "telling stories", "spending an evening with", and "having conversations" 57 . These programmatic differences assured that men did not relinquish their place as experts and denied women their individual and collective, historical and commemorative expertise. The gendered commemorative politics that was intended to cross borders also fixed them into place.

is adopted by: the Abbey Theatre, Cork Midsummer Festival, the Corn Exchange, Druid, the Everyman Theatre, Dublin Theatre Festival, Fishamble, the New Play Company, the Gate Theatre, the Lir Academy, and Rough Magic (Waking the Feminists, "10 Irish Theatre Organisations Announce Gender Policies”, on line: http://www.wakingthefeminists.org/gender_equality_in_practice).

51. Margaret Ward, "Revolutionary Women of 1916".

52. The chair, vice-chair, and seven of eleven members of the Decade of Centenaries Expert Panel are men, whereas a consultative Oireachtas Committee on Commemoration (Republic of Ireland) has a gender balanced committee membership (Decade of Centenaries (2018), Expert Group, on line: http://www.decadeofcentenaries.com/expert-group).

53. Numbers are based on first mention, not the number of times an event was programmed.

54. “One Book Two Cities”, Dublin and Belfast, programmes, on line: http://www.dublinonecityonebook. ie/wp-content/uploads/2015/11/Fallen-Programme.pdf and http://www.dublinonecityonebook.ie/ wp-content/uploads/2016/03/Belfast-Programme.pdf.

55. Panelists included authors Anna Carey, Jeanne Sutton, and poet, Nell Regan, chaired by RTÉ radio personality, Rick O’Shea.

56. “One Book Two Cities”, Belfast, programme, on line: http://www.dublinonecityonebook.ie/wpcontent/uploads/2016/03/Belfast-Programme.pdf.

57. Ibid. 


\section{Im/mobilising place-events}

Fiction is often understood as making claims about authenticity. In this context, antagonism over the Irish border made fictional claim-making a risky behaviour ${ }^{58}$. Avoiding risks by dividing conflicts limited the book's audience and their mobility, and limited the book's influence. Dublin-based participants expected and experienced fewer place-events related to World War I, and Belfast-based participants expected and experienced fewer place-events related to the Rising. Contested topics, such as pacifism, were scarcely included in either programme. The place-event, as a form of literary commemoration, was accommodated in Dublin, but it was resisted in Belfast. Intentional cross-border mobility was limited to a single reciprocal excursion in which library-based book club members met in prestigious municipal buildings, Dublin Castle and Belfast City Hall respectively, to mark the special character of their meetings ${ }^{59}$. A more engaging, but more labour intensive (and more politically contested) alternative would have been to combine Dublin-based and Belfast-based readers into a single book club whose connections would have enhanced reader-to-reader contact and communication, mobility, and challenged assumptions about readers as stationary ${ }^{60}$.

In "One Book Two Cities" programmes, places were managed purposively to minimise the potential for conflict. No book-related programmes took place, for example, in Dublin's Kilmainham Gaol, as the execution site of some of the Rising's leaders, or in Belfast's Milltown Cemetery, as an important place for republican commemoration. Yet, at the same time, the place-event was used to contribute to the difficult work of commemoration and to articulate expectations for literary reconciliation, including linking cross-border communities and fostering understanding ${ }^{61}$. Commemoration remained especially contested in Northern Ireland where unionist politicians distanced themselves from 1916 commemorations. Northern Ireland's First Minister, the DUP's (Democratic Unionist Party) Arlene Foster, declined invitations to attend $90^{\text {th }}$ year, and centenary year commemorations in Dublin $^{62}$. Due in part to disagreements over their commemorative heroes, Northern Ireland's republican communities, which are also divided, held six different 1916

58. Robert Clarke, Marguerite Nolan, "Book Clubs and Reconciliation...”.

59. Dublin City Council boasts book clubs in most city libraries. Libraries NI supports over a hundred adult reading groups (Northern Ireland Library Authority, Annual Report and Accounts 2015/2016, Belfast, Libraries NI, 2016, p. 25). On the various roles of book clubs, see Beth Driscoll, "How Oprah's Book Club Reinvented the Woman Reader"; Elizabeth Long, Book Clubs: Women and the Uses of Reading in Everyday Life, Chicago - London, University of Chicago Press, 2003; Elizabeth McHenry, Forgotten Readers: Recovering the Lost History of African American Literary Societies, Durham, Duke University Press, 2002; and, Marilyn Poole, “The Women's Chapter: Women's Reading Groups in Victoria”, Feminist Media Studies, vol. 3, no. 3, 2003, p. 293.

60. Erica Yap, "Readers-in-Conversations: A Politics of Reading in Literary Geographies", Social \& Cultural Geography, vol. 12, no. 7, 2011, p. 793-807.

61. Jackie Lyman, 2017, personal communication.

62. BBC Northern Ireland broadcasted Dublin's centenary commemoration on television and radio in Northern Ireland. 
commemorative events in Belfast's Milltown Cemetery ${ }^{63}$. In his review of Mills' Fallen, Brian Lynch speculated that the book would make "deep-green patriots" unhappy because of the exclusion of some of the Rising's main figures, notably Padraig Pearse and James Connolly ${ }^{64}$.

The place-event secured participation from readers and from non-readers, as was acknowledged by Mills ${ }^{65}$. The involvement of non-readers in mass reading events is noteworthy, but remains an underconsidered topic in analyses of mass reading events. In this example, engagement by those who had not read Fallen likely confirmed the attraction of the place-event and its place-bound connections to commemoration. It may have indicated a preference for literary engagement over political engagement and intentional place avoidance, including of public libraries and their (managed, not spontaneous) book clubs ${ }^{66}$.

\section{Conclusion}

The commemorative "One Book Two Cities" programme has the potential to contribute towards Heather Laird's ideas about the past's “jagged edges” by highlighting different aspects of stories about 1916 and commemorating these aspects in imaginative ways ${ }^{67}$. It followed Laird's recommendations by organising small-scale events that offered points of personal and corporeal connection, and by incorporating Mill's open ending where "everything lost" is also "everything starting again" ${ }^{6}$. However, the organisation of this cross-border event instead reinforced Laird's observation about the tendency of state-supported commemorations to reinforce "linear narratives", including geo-political and gendered divisions ${ }^{69}$.

Despite a publication date that preceded the commemorative year, Mills' novel Fallen was called into service to orchestrate the place-event as an extra-textual urban, commemorative, cross-border encounter. It was used by event organisers and libraries in both cities to embrace the government-led commemorative programme and to express their aspirations for literary reconciliation ${ }^{70}$. Fallen and its place-specific activities promoted an awareness of the decade of commemoration. However, its celebrations simultaneously expanded places and fixed them. Despite

63. Brendan Ciarán Browne, "Choreographed Segregation: Irish Republican Commemoration of the 1916 Easter Rising in 'Post-Conflict' Belfast”, Irish Political Studies, vol. 31, no. 1, 2016, p. 111.

64. Brian Lynch, "Books: Depicting a Very Different Strumpet City”, Irish Independent, 1 June 2014. Recognition of the Irish language in Northern Ireland is also a politically divisive topic. Fallen, available in English, Braille, and audio versions, included Irish language programming in Dublin only.

65. Lia Mills, Fallen, Dublin, Penguin, 2014.

66. Irina Van Aalst, Rianne Van Melik, "City Festivals and Urban Development: Does Place Matter?", European Urban and Regional Studies, vol. 19, no. 2, 2012, p. 197.

67. Heather Laird, Commemoration, Cork, Cork University Press, 2018, p. 79.

68. Lia Mills, Fallen, p. 276.

69. Heather Laird, Commemoration, p. 78.

70. Ciara Murphy, “Reflecting Irishness, Mirroring Histories...”, p. 123. 
its aspirations, "One Book Two Cities" provided a limited model of the potential for literary reconciliation across commemorative differences. It did, however, challenge readers to consider how books were changed by places, and it challenged organisers to consider how places were transformed by books and readers. But, even a century after 1916, the spectre of conflict persists and cross-border commemorative activities necessitate political sensitivity.

The place-event challenged ideas about reading as a solitary and stationary activity and challenged its confinement to the places of the library and the (library-endorsed) book club. Contextualised in Pink's theorising about the placeevent, "One Book Two Cities" programming highlighted corporeal, cognitive, and experiential understandings of places, texts, and literary performances ${ }^{71}$. These understandings were situated in a "complex assemblage" of historical and contemporary relationships ${ }^{72}$. However, the event's primary challenges remained logistical and political. Traversing bifurcated geographies, histories, and commemorative practices proved difficult. An unevenly balanced joint programme was offset further by demographic imbalances, varying degrees of experience with literary culture and tourism, and by the legacy of conflict that marked the two jurisdictions differently.

Dublin-based participants were emplaced through a combination of text, mobility, sensory experiences, and place, whereas Belfast-based participants were confined by place in order to limit the possibilities of social dissensus. These two distinct modes of engagement presupposed a lack of public readiness for cross-community political engagement, which was embedded in the cross-border programme ${ }^{73}$. The limited ability to programmatically bridge geographic, commemorative, and physical distances reinforced the presence and significance of their differences. A participant evaluation echoed the initiative's goals, suggesting, "It is nice to do our bit to further the normalisation of relationships between both parts of our island". However, there was little evidence that the "One Book Two Cities" mass reading event normalised relationships in the context of still contentious issues related to history, politics, and commemoration.

As a case study, the thematically focused book, the place-event, and the commemorative context in which they were located, were inadequate in achieving its programme goals to link cross-border communities through common experiences and foster cross-border understandings. It proved better able to mark the $100^{\text {th }}$ anniversary of the 1916 Rising in Dublin, and to promote the practice of book-club twinning. Despite organisers' efforts, significant political differences remained. Commemorative exclusions, including gender, were solidified. Existing alongside other efforts to address literary commemoration and promote social reconciliation, including Anouk Lang's examination of Andrea Levy's Small Island (2004) for its

71. Sarah Pink, "From Embodiment to Emplacement...", p. 352.

72. Erica Yap, “Readers-in-Conversations...”, p. 799.

73. This may have been presumed based on political unsettledness in Northern Ireland, specifically the January 2017 collapse of the Northern Ireland Executive and the role of some of its members in heated debates about Brexit. 
consideration of slavery, migration and racism in Great Britain, and Robert Clarke and Marguerite Nolan's examination of Aborigine and European settler relations in Kate Grenville's The Secret River (2005), "One Book Two Cities” reinforces the challenges of literary reconciliation and aspirations to reach "beyond the book" 74 . New directions will emerge from bolder literary works, but must emerge from the ways they are taken up in mass reading events. At the expense of attracting readers (and consumers) en masse, future steps to move towards the aspirational goals of literary reconciliation projects necessitate prioritising difficult questions, engaging politics at the expense of (some) readers' comfort, and creating unsettling place-events. All of those were avoided in this case study.

Oona Frawley argues that the difficulties of commemoration constitute "an impasse of the most polite kind" and the 2016 "One Book Two Cities" initiative proceeded in this vein ${ }^{75}$. The novel's uptake through the place-event proceeded in an unquestioned mode through which organisers maintained ideological ideas about the importance of reading, literacy, and citizenship, and confirmed the significance of history, politics, and commemoration in ways that did not unsettle the existing status quo, including existing patterns of women's exclusion. Within the confines of carefully managed places readers followed along with Fallen and "One Book Two Cities" with an eye to countering their prolonged history of distrust.

Katherine SIDE Memorial University of Newfoundland (Canada) DeNel Rehberg SEDo Mount Saint Vincent University, Halifax (Canada)

74. Danielle Fuller, DeNel Rehberg Sedo, Reading Beyond the Book: The Social Practices of Contemporary Literary Culture, New York, Routledge, 2013.

75. Oona Frawley, "Women and the Decade of Commemorations...". 